\title{
Metabolic status of crossbred Charolais $\times$ Nellore cows throughout the final third of gestation and lactation
}

\section{Estado metabólico de vacas mestiças Charolês $\times$ Nelore ao longo do terço final de gestação e da lactação}

\author{
John Lenon Klein ${ }^{1 *}$; Sander Martinho Adams ${ }^{1 ;}$ : Dari Celestino Alves Filho; \\ Fabiana Moro Maidana ${ }^{1}$; Ivan Luiz Brondani²; Joziane Michelon Cocco'; \\ Rodrigo Soares Volpatto3; Silvino Sasso Robalo ${ }^{2}$
}

\section{Highlights}

In beef cows, greater metabolic challenges occur in the first 63 days postpartum.

The concentration of energy metabolites decreases in the first weeks of lactation.

Blood metabolites vary to differing extents between final gestation and lactation.

\begin{abstract}
The objective of this study was to evaluate the metabolic status of beef cows during the final third of gestation and thereafter until the end of the subsequent breeding season. The study was conducted using 30 beef cows, aged between 4 and 11 years, derived from crosses between Charolais and Nellore cattle. To assess the metabolic status of cows, we obtained measurements of body weight and condition (BW and BCS), and complemented these by analyzing the following blood metabolites: total proteins, globulins, albumin, glucose, cholesterol, and triglycerides. Assessments were performed at 95 days pre-calving, and again at 7 , 21,63 , and 110 days post-calving. The experimental design was completely randomized with five collection periods and 30 repetitions (cows). The BW of cows was found to be highest at 110 days postpartum (489.1 $\mathrm{kg})$, and loss of BW was observed between 21 and 63 days postpartum $(-3.72 \mathrm{~kg})$. The lowest BCS value was recorded after 63 days of lactation (2.85 points). With respect to blood metabolites, concentrations of total proteins were higher at 7 and 110 days postpartum relative to the levels recorded during gestation (8.3 and 8.3 vs. $7.7 \mathrm{~g} \mathrm{dL}^{-1}$, respectively), whereas serum globulin levels were higher at 7,21 , and 110 days postpartum relative to those at gestation $\left(5.2,5.2\right.$, and 5.1 vs. $4.8 \mathrm{~g} \mathrm{dL}^{-1}$, respectively). Compared with samples obtained during gestation, the highest levels of albumin $(P<0.05)$ were observed at 7,63 , and 110 days postpartum (3.1, 3.1, and 3.2 vs. $2.9 \mathrm{~g} \mathrm{dL}^{-1}$, respectively). Serum glucose was higher during pregnancy and in the first week of lactation relative to the values recorded after 21 and 63 days of lactation (80.9 and 76.7 vs 71.5

1 Postgraduate in Animal Science, FederalUniversity of Santa Maria,UFSM, SantaMaria, RS, Brazil.E-mail:johnlenonklein@ yahoo.com.br; sander.adams@hotmail.com; f96033512@gmail.com; jozimichelon@hotmail.com

2 Profs. Drs., Department of Animal Science, UFSM, Santa Maria, RS, Brazil. E-mail: darialvesfilho@hotmail.com; ivanbrondani@gmail.com; silvinosr@gmail.com

3 Graduate in Animal Science, UFSM, Santa Maria, RS, Brazil. E-mail: rodrigovolpatto97@gmail.com

* Author for correspondence
\end{abstract}

Received: July 07, 2020 - Approved: Feb. 04, 2020 
and $72.3 \mathrm{mg} \mathrm{dL}^{-1}$, respectively). Moreover, cholesterol concentrations increased with the progression of lactation, with the highest value being recorded at 110 days postpartum ( $\left.222.1 \mathrm{mg} \mathrm{dL}^{-1}\right)$. Collectively, the findings of this study, indicate that Charolais $\times$ Nellore cows raised exclusively on native pasture mobilize body reserves, lose weight, and show a negative energy balance during the first weeks of lactation, with detrimental consequences for subsequent reproductive activity.

Key words: Body condition. Blood metabolite. Glucose. Reproduction.

\section{Resumo}

Avaliar o estado metabólico de vacas de corte do terço final de gestação até o final da estação reprodutiva subsequente foi o objetivo do presente estudo. Foram utilizadas trinta vacas de corte, oriundas do cruzamento entre as raças Charolês e Nelore, com idade entre 4 a 11 anos. Para avaliação do estado metabólico das vacas, foram tomadas as medidas de peso e escore de condição corporal (PC e ECC), sendo estas variáveis complementadas pela análise dos metabólitos sanguíneos: proteínas totais, globulinas, albumina, glicose, e colesterol e triglicerídeos. Estas avaliações foram realizadas aos 95 dias pré-parto e aos sete, 21, 63 e 110 dias após a parição. $O$ delineamento experimental foi o inteiramente casualizado com cinco períodos de coleta e 30 repetições (vacas). As vacas apresentaram o maior PC aos 110 dias pós-parto (489,1kg). Foi observado perda de PC entre 21 e 63 dias pós-parto $(-3,72 \mathrm{~kg})$. Menor valor de ECC foi obtido aos 63 dias de lactação (2,85 pontos). A concentração das proteínas totais foi maior aos sete e 110 dias pósparto em relação aos níveis obtidos durante a gestação (8,3 e 8,3 vs. 7,7 $\mathrm{g} \mathrm{dL}^{-1}$, respectivamente). Níveis séricos de globulinas foram maiores aos sete, 21 e 110 dias pós-parto em relação à gestação $(5,2 ; 5,2$ e 5,1 vs. 4,8 $\mathrm{g} \mathrm{dL}^{-1}$, respectivamente). Os maiores níveis de albumina foram observados aos sete, 63 e aos 110 dias pós-parto quando comparados à amostragem durante a gestação $\left(3,1 ; 3,1\right.$ e, 3,2 vs. 2,9 g dL ${ }^{-1}$, respectivamente). A glicose sérica foi maior durante a gestação e na primeira semana de lactação em relação às coletas realizadas aos 21 e 63 dias de lactação (80,9 e 76,7 vs 71,5 e 72,3 mg dL ${ }^{-1}$, respectivamente). A concentração de colesterol aumentou com o avanço da lactação, com maior valor aos 110 dias pós-parto $\left(222,1 \mathrm{mg} \mathrm{dL}^{-1}\right)$. Vacas Charolês $\times$ Nelore criadas exclusivamente em pastagem nativa mobilizam reservas corporais, perdem peso e apresentam quadro de balanço energético negativo nas primeiras semanas de lactação, com consequências na atividade reprodutiva subsequente.

Palavras-chave: Condição corporal. Glicose. Metabólitos sanguíneos. Reprodução.

\section{Introduction}

Pregnant beef cows are normally
maintained in extensive forage-based
rearing systems. These forage systems are
characterized by variations in food supply
during the year, subjecting cows to food
restriction and potential malnutrition during
the most challenging periods (Gutiérrez et al.,
2014), such as the end of pregnancy and the

beginning of lactation. Food shortages are common in several regions of the world, and thus it is important to monitor the nutritional condition of cows, which is often based on a visual assessment of body condition, expressed in terms of the body condition score (BCS) (Torres, Tineo, \& Raidan, 2015).

TheBCSrepresentsananimal'sreserves that can be drawn upon during periods of food scarcity and, according to Silva et al. (2016), this 
variable can be used as an indicator of negative energy balance, a condition where the nutrient intake of cows is lower than their metabolic demands. According to Kenyon, Maloney and Blache (2014), the BCS is a good criterion for assessing an animal's energy status due to the ease of visualizing the reserves of muscle and fat tissue along the backbone. A low supply of nutrients during pregnancy, for example, promotes the mobilization of body reserves to maintain an adequate supply of nutrients for fetal growth (Webb et al., 2019). During lactation, the mammary glands take priority with respect to the partitioning of nutrients within the body, and can account for up to $60 \%$ to $85 \%$ of the ingested glucose (Duarte et al., 2015). Given that feed or forage intake at the beginning of lactation is lower than nutritional requirements, the BCS is reduced to supply multiple demands, particularly for energy.

In addition to an evaluation of BCS, the assessment of blood metabolites has been used to identify metabolic disorders during the postpartum period of beef cows, and can provide an indication of nutritional status (Silveira et al., 2012). Monitoring these metabolites can contribute to the prevention of metabolic disorders and thus promote better health conditions for the herd and reduce the likelihood of reductions in the rates productivity and reproduction (Bolzan et al., 2011). Thus, the objective of the present study was to evaluate, through variations of BCS and blood metabolites, the dynamics of the metabolic status of beef cows during the final third of gestation and thereafter until the end of the subsequent breeding season.

\section{Materials and Methods}

The research protocols employed in the present study were carried out in accordance with the Ethics Committee on the Use of Animals (CEUA) of the Federal University of Santa Maria, under protocol No. 7920140617, approved on July 12, 2017.

The study was conducted from April 15, 2017 to May 15, 2018, at a site in the municipality of Santa Maria, RS, Brazil (29\%43'S, $53^{\circ} 42^{\prime} \mathrm{W}$ ), which has an average altitude of 95 $\mathrm{m}$. A representative sample of 30 pregnant crossbred Charolais $\times$ Nellore beef cows was randomly selected from a herd of 200 cows of the same breed. The sample was comprised of cows from the fourth and fifth generations of the crossbreds, with ages ranging from 4 to 11 years (Table 1).

\section{Table 1}

Distribution of the genetic groups among the crossbred Charolais $(\mathrm{CH}) \times$ Nellore (NE) cows used in the present study

\begin{tabular}{|ccc|}
\hline Genetic group & Cows $(\mathrm{n})$ & Age (years) \\
\hline $11 / 16 \mathrm{CH} \times 5 / 16 \mathrm{NE}$ & 4 & $8.0 \pm 2.4$ \\
\hline $11 / 16 \mathrm{NE} \times 5 / 16 \mathrm{CH}$ & 4 & $7.5 \pm 2.0$ \\
\hline $21 / 32 \mathrm{CH} \times 11 / 32 \mathrm{NE}$ & 8 & $7.3 \pm 2.7$ \\
\hline $21 / 32 \mathrm{NE} \times 11 / 32 \mathrm{CH}$ & 13 & $7.5 \pm 1.7$ \\
\hline
\end{tabular}


The animals were maintained in four paddocks of natural pasture with areas of $20,21,41$, and 47 ha, respectively, in each of which, ProduBeef $60 \mathrm{P}^{\circledR}$ mineral salt was freely available. The native pasture was composed predominantly of Eragrostis plana Ness, a summer species of African origin (approximately 60\%), referred to locally as capim-annoni, as well as other warm season grass species, including Paspalum notatum, Axonopus affinis, and Desmodium incanum. The pasture vegetation (samples of the total forage cut) has crude protein, neutral detergent fiber, and total digestible nutrient contents of 49.0, 795, and $350.0 \mathrm{~g} \mathrm{~kg}^{-1}$, respectively, on a dry matter (DM) basis. Although the cow were grazed continuously, they were rotated among paddocks at 28-day interval to reduce the likelihood of potential confounding effects. The forage mass and forage allowance in the paddocks, evaluated at 14-day intervals, were $4144 \pm 164 \mathrm{~kg} \mathrm{DM} \mathrm{ha}^{-1}$ and $11 \pm 1 \mathrm{~kg} \mathrm{DM}$ per $100 \mathrm{~kg}$ animal body weight (BW), respectively. The average stocking was equivalent to 275 $\pm 49 \mathrm{~kg} \mathrm{BW} \mathrm{ha}^{-1}$. Calving occurred between October 25 and December 15, 2017, after which, the mothers and newborns were taken to a management center for the weighing of both and initial care of the calf, and were later relocated to a natural pasture paddock until weaning (165 \pm 12 days of age).

The breeding season commenced 21 \pm 7 days after calving, and in this regard, we aimed to maintain the same interval between calving and the beginning of reproduction for all cows. The period of reproduction continued from December 4, 2017 until February 28, 2018 , with the time of exposure of cows to breeders ranging from 55 to 86 days. A natural breeding method was used, with a ratio of one bull to 25 cows ( 8 bulls for the
200 cows in the herd), with the breeders being subjected to andrological examination prior to the reproductive season. The bulls belonged to the Charolais and Nellore breeds, with the Charolais and crossbred Nellore cows being submitted to the Charolais bulls, according to the rotational crossing scheme between the breeds. Pregnancy was confirmed using an ultrasound device 45 days after the bulls had been removed from the herd.

During the final phase of gestation and thereafter until the end of the subsequent breeding season, we monitored changes in the BW and BCS of cows. Weighing and BCS assessments were performed on the following occasions: at the beginning of the final third of gestation (95 days before calving); 7 days postpartum ( \pm 3 days); and at the beginning (21 \pm 7 days postpartum), mid-point $(63 \pm 12$ days postpartum), and end of the subsequent reproductive season $(110 \pm 12$ days postpartum). Weight gain was calculated as the difference in BW between two consecutive weighings. BCSvalues were takenas anaverage of the scores of two trained evaluators, based on a scale of 1 to 5 , as described by Torres et al. (2015), where animals classified as 1 and 5 are respectively considered to be overly lean and excessively fat. Owing to difficulties and necessary precautions with respect to the handling cows with advanced pregnancies and during the post-calving period, when calves remain close to their mothers, sampling was carried out at pre-defined time points along with other herd management processes, which explains why sampling was conducted at different intervals.

In order to complement assessments of the metabolic status of cows at different physiological stages, blood samples were taken to determine the serum concentrations of 
blood metabolites. The serum concentrations of the following selected metabolites were determined using the indicated Labtest $^{\circledR}$ commercial kits: total proteins (Ref. No. 99250), albumin (Ref. No. 19.1/250), glucose (Ref. No. 133.1/500), cholesterol (Ref. No. 76.2/100), and triglycerides (Ref. No. 87.2/100). In addition, globulin concentrations were determined as the difference between total proteins and albumin. On the same days as we performed weighings and BCS assessments, blood samples were taken from the jugular vein and subsequently stored in 10-mL Vacutainer ${ }^{\circledR}$ tubes without any additives. After collection, the samples were centrifuged at $3000 \mathrm{rpm}$ for 10 min to obtain blood serum, which was stored in 2-mL Eppendorf tubes and subsequently maintained at a temperature of $-20^{\circ} \mathrm{C}$ until used for biochemical analyses.

The experimental design used was completely randomized with five periods of collection and 30 replicates (cows). The normality of the residuals was analyzed using the Shapiro-Wilk test, and the elimination of outliers was performed when necessary. The residuals for serum triglycerides were square root transformed to adjust the data to a normal distribution. The elimination of outliers was performed after attempting to transform the residuals, eliminating data with dispersion outside a range of \pm 2 standard deviations, with animals being eliminated only for the specific variable. Subsequently, analysis of variance was performed using the PROC MIXED model, based on the covariance structure with the lowest Akaike information criterion (AIC) value. When significant values were obtained, the means were compared using the Tukey-Kramer test at a probability of 0.05 . Statistical analyses were performed using the statistical package SAS $^{\circledR}$ Studio University Edition (version 3.5), based on the following mathematical model:

$$
Y_{i j k m}=\mu+P_{i}+I_{j}+Z_{k}+\operatorname{Rep}(P)_{m}+\varepsilon_{i j k m}
$$

where, $Y_{i j k}$ is the dependent variable, $\mu$ is the average of all observations, $P_{i}$ is the effect of the $i$-th collection period, $I_{j}$ is the effect of the co-variable cow age, $Z_{k}$ is the effect of the covariable percentage of the Nellore breed on cows; $\operatorname{Rep}(\mathrm{P})_{m}$ is effect of the repetition in each period; and $\varepsilon_{i j k}$ is the effect of residual random error.

In addition, Pearson correlation analysis was performed to assess associations of the variables of interest, using the PROC CORR command from the same SAS statistical package, with correlation coefficients up to 0.10 of probability. All variance effects were included in a regression using the PARTIAL command of the correlation analysis.

\section{Results and Discussion}

Measurements of the BW of cows during the period of observation revealed that the highest weights were attained at 110 days postpartum (489.1 kg) (Table 2). The nutritional requirements of cows begin to increase during the final third of the gestation period, during the last 3 months of which, the fetus grows by approximately $70 \%$ of its potential (Bauman \& Bruce Currie, 1980), and reaches a peak during the periods of calving and reconception (Santos, Abreu, Souza, \& Catto, 2009). 
Table 2

Distribution of the genetic groups among the crossbred Charolais $(\mathrm{CH}) \times$ Nellore $(\mathrm{NE})$ cows used in the present study

\begin{tabular}{ccccccc}
\hline \multirow{2}{*}{ Variable $^{1}$} & -95 & 7 & 21 & 63 & P-value \\
\cline { 2 - 6 } BCS (points) & $2.90 \pm 0.1 \mathrm{a}$ & $2.92 \pm 0.1 \mathrm{a}$ & $2.90 \pm 0.1 \mathrm{a}$ & $2.85 \pm 0.1 \mathrm{~b}$ & $2.92 \pm 0.1 \mathrm{a}$ & 0.0136 \\
BW (kg) & $462.6 \pm 4.8 \mathrm{~b}$ & $470.9 \pm 2.3 \mathrm{~b}$ & $471.8 \pm 1.7 \mathrm{~b}$ & $465.5 \pm 3.9 \mathrm{~b}$ & $489.1 \pm 2.5 \mathrm{a}$ & 0.0002 \\
& - & -95 to 7 & 7 to 21 & 21 to 63 & 63 to 110 \\
BW variation $(\mathrm{kg})$ & - & $8.27 \pm 4.5 \mathrm{~b}$ & $0.89 \pm 3.9 \mathrm{~b}$ & $-3.72 \pm 4.3 \mathrm{~b}$ & $23.20 \pm 5.8 \mathrm{a}$ & 0.0019 \\
\hline
\end{tabular}

${ }^{1}$ BCS: body condition score (1 = very thin; 2 = thin; 3 = average; 4 = fat; 5 = very fat); BW: body weight.

Averages in rows denoted by different letters differ significantly, as determined using the Tukey-Kramer test $(P<0.05)$.

Between days 21 and 63 of lactation, we recorded a $3.72 \mathrm{~kg}$ loss in BW. Subsequently, however, there was a recovery in the amounts of body reserves and greater BW gain from 63 to 110 days postpartum $(23.20 \mathrm{~kg}$; Table 2). Likewise, beef cows showed mobilization of body reserves during the lactation period, reaching. $\mathrm{BCS}$ at 63 days of lactation $(2.85$ points) (Table 2). According to Parr et al. (2015), the BCS loss after calving is a consequence of a negative energy balance, as cows ingest less nutrients during this period relative to the demands for maintenance and milk production. Both BW and BCS losses during pregnancy or at the beginning of lactation can affect future reproductive performance, as it can results in a longer interval between calving and conception (Colazo, Hayirli, Doepel, \& Ambrose, 2009). In this regard, we found that the BW and BCS of cows at calving showed a positive correlation with the rate of pregnancy $(r=0.29$ and 0.49 , respectively).

The importance of BW and BCS has also reported by Cooper-Prado et al. (2018), who concluded that during the breeding season, performance is more closely related to these traits than the rates of $\mathrm{BW}$ and $\mathrm{BCS}$ gain. This is verified in cows characterized by low BCS at calving, which, although recovering after calving, may not necessarily undergo subsequent conception. These findings are in line with the observations reported by Torres et al. (2015), who stated that the BCS interferes with the probability of pregnancy in cows, and that an increase of 0.5 points in BCS at the time of the implementation of a fixed-time artificial insemination protocol corresponds to a $39 \%$ increase in the probability of pregnancy in beef cows. The same authors stated that the best results were obtained under conditions where cows had a BCS greater than 3.0 on a scale of 1 to 5 points, with 3.5 points being considered ideal. In the present study, the assessed BCS at the end of the breeding season (110 days postpartum) was 2.92 points, a factor that may explain the low percentage of cows that undergo repeated pregnancies and the high proportion of cows in deep anestrus at the time of pregnancy diagnosis $(24.09 \%$ and $75.91 \%$, respectively). In this regard, when assessing the effects that most interfere with successive pregnancies, Joner et al. (2018) observed that the low BCS of cows reduces the likelihood of reconception and success in calf production. 
The low reproductive performance of cows may also have been attributable to concentration of certain metabolites that influence reproduction and the release of reproductive hormones. In this regard, we found that the concentration of total proteins in the serum of cows was higher at 7 and 110 days postpartum relative to the levels observed during gestation (8.3 and 8.3 vs. $7.7 \mathrm{~g} \mathrm{dL}^{-1}$, respectively; Table 3). Although these metabolites tend to vary according to physiological state, the serum levels measured in the present study were found to be close to the range (6.74 and $7.46 \mathrm{~g} \mathrm{dL}^{-1}$ ) suggested by Kaneko, Harvey and Bruss (2008). A similar pattern was observed with respect to serum globulin levels, with lower values being recorded during final phase of gestation compared with those measured at 7,21 , and 110 days postpartum (4.8 vs. 5.2; 5.2 and 5.1 $\mathrm{g} \mathrm{dL}^{-1}$, respectively). Our hypothesis in this respect is that lower levels of these metabolites during pregnancy may be related to an elevated rate of immunoglobulins synthesis for the formation of colostrum, which is the first milk produced by cows that contributes to the passive transmission of immunity to newborn calves.

\section{Table 3}

\section{Means and standard errors obtained for blood metabolites of Charolais $\times$ Nellore cows at different} physiological stages

\begin{tabular}{|c|c|c|c|c|c|c|}
\hline \multirow{2}{*}{ Variable $^{1}$} & \multicolumn{5}{|c|}{ Days in relation to calving } & \multirow{2}{*}{$P$-value } \\
\hline & -95 & 7 & 21 & 63 & 110 & \\
\hline Total proteins $\left(\mathrm{g} \mathrm{dL}^{-1}\right)$ & $7.7 \pm 0.1 c$ & $8.3 \pm 0.1 a$ & $8.2 \pm 0.1 \mathrm{ab}$ & $8.1 \pm 0.1 b c$ & $8.3 \pm 0.1 a$ & 0.0043 \\
\hline Globulins (g dL-1) & $4.8 \pm 0.1 b$ & $5.2 \pm 0.1 a$ & $5.2 \pm 0.1 a$ & $5.0 \pm 0.1 \mathrm{ab}$ & $5.1 \pm 0.1 a$ & 0.0224 \\
\hline Albumin $\left(\mathrm{g} \mathrm{dL}^{-1}\right)$ & $2.9 \pm 0.1 b$ & $3.1 \pm 0.1 a$ & $3.0 \pm 0.1 \mathrm{ab}$ & $3.1 \pm 0.1 a$ & $3.2 \pm 0.1 a$ & 0.0010 \\
\hline Glucose (mg dL-1) & $80.9 \pm 2.9 a$ & $76.7 \pm 1.4 a$ & $71.5 \pm 1.2 b$ & $72.3 \pm 1.5 b$ & $75.2 \pm 1.3 a b$ & 0.0008 \\
\hline Cholesterol (mg dL-1) & $146.6 \pm 7.8 \mathrm{c}$ & $122.1 \pm 7.9 d$ & $137.6 \pm 2.1 \mathrm{c}$ & $176.8 \pm 7.2 b$ & $222.1 \pm 6.8 a$ & 0.0002 \\
\hline Triglycerides (mg dL $\mathrm{m}^{-1}$ ) & $24.2 \pm 1.8$ & $22.9 \pm 4.2$ & $28.6 \pm 5.2$ & $25.0 \pm 5.1$ & $21.2 \pm 2.3$ & 0.4989 \\
\hline
\end{tabular}

Averages in rows denoted by different letters differ significantly, as determined using the Tukey-Kramer test $(\mathrm{P}<0.05)$.

Among the metabolites assessed in the present study, glucose and albumin are directly related to energy and protein metabolism, respectively, and play direct roles in the contro of reproduction. We found that there was a moderate positive correlation between these blood metabolites ( $r=0.45$; Table 4). Higher levels of albumin were observed at 7,63 , and 110 days postpartum when compared with levels recorded during pregnancy $(3.1,3.1$, and 3.2 vs. $2.9 \mathrm{~g} \mathrm{dL}^{-1}$, respectively; Table 3). For both protein parameters, we detected a slight reduction in concentrations during the first month of lactation. In terms of reproduction, Bolzan et al. (2011) stated that cows that maintain stable albumin concentrations after calving tend to be more fertile than those with reduced levels of this metabolite. Consistently, Smuts, De Bruyn, Thompson and Holm (2019) stated that albumin is the most abundant protein in blood, and concluded that adequate levels of this metabolite are a significant 
predictor of the competence of cows to produce healthy oocytes, which is an essential factor for obtaining high conception rates. The authors also indicated that a concentration of this metabolite greater than $3.60 \mathrm{~g} \mathrm{dL}^{-1}$ is necessary in order to avoid negative outcomes in the production of viable oocytes and, consequently, in embryonic development.

Table 4

Pearson correlation coefficients for the concentration of blood metabolites in Charolais $\times$ Nellore cows

\begin{tabular}{cccccc}
\hline Variable & Proteins & Globulins & Albumin & Glucose & Cholesterol \\
\hline Globulins & $0.92^{* * *}$ & & & \\
\hline Albumin & $0.56^{* * *}$ & $0.21^{* *}$ & & \\
\hline Glucose & $0.26^{* * *}$ & NS & $0.45^{* * *}$ & & \\
Cholesterol & $0.16^{*}$ & NS & $0.32^{* * *}$ & $0.24^{* * *}$ & \\
Triglycerides & NS & NS & NS & NS & $0.18^{* *}$
\end{tabular}

NS - Non-significant $(P>0.10)$; ${ }^{*}$ Significance at $10 \%$ probability $(P<0.10) ;{ }^{* *}$ Significance at $5 \%$ probability $(P<0.05)$; $* * *$ significance at $1 \%$ probability $(P<0.01)$.

The higher nutrient demand of beef cows during the first months of lactation was also evident when we evaluated concentrations of serum cholesterol and particularly glucose (Table 3), the latter of which is directly associated with the volume of milk produced by the mammary glands. The highest levels of serum glucose were observed during pregnancy and the first week of lactation compared with the levels recorded after 21 and 63 days of lactation ( 80.9 and 76.7 vs. 71.5 and $72.3 \mathrm{mg} \mathrm{dL}^{-1}$, respectively), which are values close to those obtained by Cooper-Prado et al. (2018). Glucose represents the main metabolic source required by cows to maintain mammary gland function during the lactation phase, which may account for between $60 \%$ and $85 \%$ of the available glucose (Duarte et al., 2015). In this regard, Adams (2019) found that the highest volumes of milk were produced after 7 , 21 , and 63 days of lactation in relation to that produced at 110 days postpartum $(6.37,6.33$, and 5.72 vs. 5.37 liters day ${ }^{-1}$, respectively). In the present study, we found that the lowest levels of serum glucose were detected during the first 63 days of lactation (Table 2), which reflects the high mammary gland demand during this period. Similarly, when assessing glucose levels in beef cows, Morales Piñeyrúa, Fariña and Mendoza (2018) also observed lower plasma glucose levels during the first weeks postpartum.

A further important function of blood glucose is the control of reproduction (Silveira et al., 2012). According to Wetteman, Lents, Ciccioli, White and Rubio (2003), glucose is the first metabolic nutrient used by the central nervous system, and in this respect, an inadequate availability of glucose has been shown to reduce the hypothalamic release of gonadotropin-releasing hormone $(\mathrm{GnRH})$, an essential hormone involved in regulation of the estrous cycle in females. Silva et al. (2016) stated that low glucose levels lead to a lower release of follicle stimulating and luteinizing hormones (FSH and $\mathrm{LH}$, respectively), in 
addition to impairing the follicular growth of cows, whereas according to Astessiano et al. (2013), in response to an increase in blood glucose, beef cows can reduce anestrus, as a consequence of the improved nutritional conditions during the reproductive period.

During lactation, there is a reduction in the use of glucose by insulin-sensitive adipose and muscle tissues, as less insulin is produced after calving (McArt, Nydam, Oetzel, Overton, \& Ospina, 2013). In addition to this insulin resistance, there is an intense mobilization of body fat in response to the greater sensitivity of adipose tissue to catecholamines (Holtenius, Agenäs, Delavaud, \& Chilliard, 2003). Collectively, these factors thus contribute to maintaining the supply of glucose to the mammary glands.

Lipolysis of adipose tissue may explain the loss of BCS recorded in the present study (Table 2), as well as the higher levels of blood cholesterol seen in cows as the period of lactation advanced (Table 3). We found that concentrations of cholesterol in the cow examined in the present study were higher at the end of the reproductive season at 110 days postpartum (222.1 $\left.\mathrm{mg} \mathrm{dL}^{-1}\right)$, with levels of this metabolite increasing with progression of the period of lactation. The values we obtained are notably higher than those suggested by Kaneko et al. (2008), who reported that the normal concentrations of this metabolite range between 80 and $120 \mathrm{mg} \mathrm{dL}^{-1}$.

In contrast to the aforementioned metabolites, we detected no significant variation in the levels of serum triglyceride, a more stable metabolite, throughout pregnancy and lactation (Table 3), with an average value of $24.9 \mathrm{mg} \mathrm{dL}^{-1}$ being recorded. Along with cholesterol, this metabolite reflects the lipid metabolism of animals (Silveira et al., 2012). The same authors observed a linear reduction in triglyceride levels in the blood of cows as lactation progressed, a finding that is indicative of the high metabolic demands and the heightened use of this metabolite by cows for milk production. In addition, we detected no significant correlation between triglycerides and cholesterol $(r=0.18$; Table $4)$, as the former shows little variation in cows. In contrast, regardless of the sampling period, we observed correlations among the other evaluated blood metabolites (Table 4), with high correlations being found between total proteins and globulins and albumin $(r=0.92$ and 0.56 , respectively).

Collectively, the findings of the present study indicate that beef cows have a negative energy balance during the initial period of lactation, which has a detrimental effect with respect to the resumption of reproductive activity, as reflected in the low rates pregnancy in cows during the subsequent breeding season. Thus, an evaluation of BW and BCS, in conjunction with determinations of the blood concentrations of certain metabolites, such as glucose, can make an important contribution to decision-making and characterizing the relevant reproductive indices pertaining to production systems. In this regard, nutritional strategies, such as feed supplementation or grazing on cultivated pastures, can be applied to reduce the negative energy balance commonly seen in cows during the initial weeks of lactation, a period of high milk production and low forage consumption capacity. In addition, early or temporary weaning techniques, such as early and interrupted weaning, respectively, can contribute to facilitating the resumption of postpartum heat, and consequently increase the productive efficiency of cows. 


\section{Conclusions}

Charolais $\times$ Nellore crossbred cows maintained exclusively in natural pastures mobilize their body reserves until 63 days postpartum, with lower body weight values and body condition scores being recorded during this period of lactation.

Serum concentrations of total proteins and albumin were found to be lower during the gestation period, whereas glucose concentrations decline during the first months of lactation until 63 days postpartum. In contrast, the levels of cholesterol increase with progression of the lactation period, reflecting the mobilization of body reserves during this period.

\section{References}

Adams, S. M. (2019). Nutrição pré-parto da vaca e seus reflexos na produção e composição do leite e no desempenho do bezerro. Dissertação de mestrado, Universidade Federal de Santa Maria, Santa Maria, RS, Brasil.

Astessiano, A. L., Pérez-Clariget, R., Espasandín, A. C., López-Mazz, C., Soca, P., \& Carriquiry, M. (2013). Metabolic, productive and reproductive responses postpartum short-term supplementation in primiparous beef cows. Revista Brasileira de Zootecnia, 42(4), 246-253. doi: 10.1590/ S1516-35982013000400003

Bauman, D. E., \& Bruce Currie, W. (1980). Partitioning of nutrients during pregnancy and lactation: a review of mechanisms involving homeostasis e homeorhesis. Journal ofDairy Science, 63(1), 1514-1529. doi: 10.3168/jds.S0022-0302(80)83111-0
Bolzan, R. P., Stradiotti, D., Jr., Penna, C. O., Jr., Binoti, D. H. B., Lima, R. A., \& Shimoda, E. (2011). Perfil metabólico proteico em dois grupos genéticos de vacas Primíparas Holandês x Gir, em dois períodos da lactação, no período da seca nos trópicos. Revista Científica de Produção Animal, 13(1), 94-99. doi: 10. 15528/2176-4158/ rcpa.v13n1p94-99

Colazo, M. G., Hayirli, A., Doepel, L., \& Ambrose, D. J. (2009). Reproductive performance of dairy cows is influenced by prepartum feed restriction and dietary fatty acid source. Journal of Dairy Science, 92(1), 2562-2571. doi: 10.3168/jds.2008-1517

Cooper-Prado, M. J., Rubio, I., Long, N. M., Davis, M. P., Spicer, L. J., \& Wettemann, R. P. (2018). Effects of body weight gain and bovine somatotropin treatment of postpartum beef cows on concentrations of IGF-1, insulin, and glucose in blood plasma; luteal activity; and calf growth. The Professional Animal Scientist, 34(1), 513-521. doi: 10.15232/pas.2018-01746

Duarte, M. F., Jr., Zervoudakis, K., Zervoudakis, J. T., Tsuneda, P. P., Silva, J. A., Silva, R. P.,... Almeida, R. D. (2015). Suplementação de fêmeas bovinas em pastejo: aspectos nutricionais e reprodutivos. PubVet, 9(7), 321-336. doi: pubvet.com.br/artigo/238

Gutiérrez, V., Espasandín, A. C., Machado, P., Bielli, A., Genovese, P., \& Carriquiry, M. (2014). Effects of calf early nutrition on muscle fiber characteristics and gene expression. Livestock Science, 167(1), 408-416. doi: 10.1016/j.livsci.2014.07.010

Holtenius, K., Agenäs, S., Delavaud, C., \& Chilliard, Y. (2003). Effects of feeding intensity during the dry period: metabolic and hormonal responses. Journal of Dairy 
Science, 86(1), 883-891. doi: 10.3168/jds. S0022-0302(03)73671-6

Joner, G., Alves, D. C., Fo., Brondani, I. L., Borchate, D., Klein, J. L., Domingues, C. C.,... Machado, D. S. (2018). Partum and postpartum characteristics on the postpartum rebreeding in beef cattle. Anais da academia brasileira de ciências, 90(Suppl. 1), 2479-2490. doi: 10. 1590/0001-3765201820171005

Kaneko, J. J., Harvey, J. W., \& Bruss, M. C. (2008). Clinical biochemistry of domestic animals (6nd ed.). San Diego: Academic Press.

Kenyon, P. R., Maloney, S. K., \& Blache, D. (2014). Review of sheep body condition in relation to production characteristics. NewZealand Journal of Agricultural Research, 57(1), 3864. doi: 10.1080/ 00288233.2013.857698

McArt, J. A. A., Nydam, D. V., Oetzel, G. R., Overton, T. R., \& Ospina, P. A. (2013). Elevated non-esterified fatty acids and $\beta$-hydroxybutyrate and their association with transition dairy cow performance. Veterinary Journal, 198(3), 560-570. doi: 101016/j.tvjl.2013.08.011

Morales Piñeyrúa, J. T. M., Fariña, S. R., \& Mendoza, A. (2018). Effects of parity on productive, reproductive, metabolic and hormonal responses of Holstein cows. AnimalReproduction Science, 191(1),9-21. doi: 10.1016/j.anireprosci.2018.01.017

Parr, M. H., Crowe, M. A., Lonergan, P., Evans, A. C. O., Fair, T., \& Diskin, M. G. (2015). The concurrent and carry over effects of long term changes in energy intake before insemination on progeny per artificial insemination in heifers. Animal Reproduction Science, 157(1), 87-94. doi: 10.1016/J. ANIREPROSCI.2015.03.019
Santos, S. A., Abreu, U. G. P. D., Souza, G. D. S., \& Catto, J. B. (2009). Condição corporal, variação de peso e desempenho reprodutivo de vacas de cria em pastagem nativa no pantanal. Revista Brasileira de Zootecnia, 38(2), 354-360. doi: 10.1590/ S1516-35982009000200019

Silva, V. L., Borges, I., Araújo, A. R., Costa, H. H. A., Alves, F. M., Fo., Inácio, D. F. S.,... Alcântara, P. B. X. (2016). Importância da nutrição energética e proteica sobre a reprodução em ruminantes. Acta Kariri Pesquisa e Desenvolvimento, 1(1), 38-47. doi: actakariri.crato.ifce.edu.br/index.php/ actakariri/article/ view/5

Silveira, M. F., Restle, J., Menezes, L. F. G., Brondani, I. L., Nörnberg, J. L., \& Callegaro, A. M. (2012). Metabólitos sanguíneos de vacas de corte suplementadas ou não com Sais de cálcio de ácidos graxos durante o período pré e/ou pós-parto. Arquivo Brasileiro de Medicina Veterinária

e Zootecnia, 64(6), 1418-1426. doi: $10.1590 / S 0102-09352012000600003$

Smuts, M. P., De Bruyn, S., Thompson, P. N., \& Holm, D. E. (2019). Serum albumin concentrationofdonorcowsasanindicator of developmental competence of oocytes. Theriogenology, 125(1), 184-192. doi: 10.1016/j.theriogenology.2018.09.002

Torres, H. L., Tineo, J. O., \& Raidan, F. S. S. (2015). Influência do escore de condição corporal na probabilidade de prenhez em bovinos de corte. Archivos de Zootecnia, 64(247), 255-260. doi: 10.21071/ az.v64i247.403

Webb, M. J., Block, J. J., Funston, R. N., Underwood, K. R., Legako, J. F., Harty, A. A.,... Blair, A. D. (2019). Influence of maternal protein restriction in primiparous 
heifers during mid and/or late-gestation on meat quality and fatty acid profile of progeny. Meat Science, 152(1), 31-37. doi: 10.1016/j.meatsci. 2019.02.006
Wetteman, R. P., Lents, C. A., Ciccioli, L. H., White, F. J., \& Rubio, I. (2003). Nutritional and suckling mediated anovulation in beef cows. Journal of Animal Science, 67(1), 785-793. doi: 10.2527/2003.81 14_ suppl_2E48 